\title{
Surface conductance and energy exchange in an intensively managed peat pasture
}

\author{
B. O. M. Dirks ${ }^{1, *}$, A. Hensen ${ }^{2}$ \\ ${ }^{1}$ Wageningen Agricultural University, Dept of Theoretical Production Ecology, PO Box 430, 6700 AK Wageningen, \\ The Netherlands \\ ${ }^{2}$ N etherlands Energy Research Foundation, PO Box 1, 1755 ZG Petten, The Netherlands
}

\begin{abstract}
Aerodynamic measurements of latent $(\lambda E)$ and sensible heat $(H)$ exchange were made in an intensively managed peat pasture during 2 consecutive years; the fetch was approximately $1.5 \mathrm{~km}$. The surface conductance $\left(g_{s}\right)$ was calculated from the Penman-Monteith equation. The analysis focused on 2 successive aspects of $g_{s}: g_{s}$ as a function of environment (primarily vapour pressure deficit [D]) and the energy balance as a function of $g_{s}$. The effect of $D$ on $g_{s}$ consisted of 2 components: the range of $D$ over which $g_{s}$ was reduced (beyond inflection point $D_{i}$ ) and the reducing effect per unit $D$. As average $D$ increased, so did inflection point $D_{i}$ and the range of $D$ over which $g_{s}$ was reduced; the reducing effect per unit $D$ decreased. $g_{s}$ was a strong mediator in the energy balance. $\lambda E$ increased with $D$ upto the inflection point $D_{i}$, beyond which $g_{s}$ increasingly offset the positive effect of $D$. As $g_{s}$ impaired $\lambda E$, the surface to air temperature difference $(\Delta T)$ and consequently $H$ increased. With increasing $g_{s}, \lambda E$ and $H$ added up to progressively lower values, suggesting an increasing soil heat flux. Hysteresis in the diurnal patterns of the energy balance showed that the positive effect of $D$ on $\lambda E$ remained stronger than the consequent negative effect of $g_{s} . \lambda E$ was higher after than before noon, whereas $\Delta \mathrm{T}$ and $\mathrm{H}$ were lower.
\end{abstract}

KEY WORDS: Aerodynamic technique - Surface conductance - Energy exchange - Latent heat · Sensible heat · Pasture $\cdot$ Grassland

\section{INTRODUCTION}

Surface conductance $\left(g_{s}\right)$ is important in atmosphericbiospheric mass and energy exchange. It is a key factor in canopy $\mathrm{CO}_{2}$ assimilation and directly determines the latent heat flux $(\lambda E)$, more so than the sensible heat flux $(\mathrm{H})$ and the soil heat flux $(\mathrm{G})$. In the energy balance, $g_{s}$ is the only biological mediator, whereas the other factors are merely imposed upon the surface.

The effect of $g_{s}$ and environment on $\lambda E$ varies widely among vegetation types and environmental conditions (Bal docchi 1994). Hiyama et al. (1995) found a substantial divergence in net irradiance $\left(R_{n}\right), \lambda E, H$ and $G$ for different surface types. J arvis \& M CNaughton (1986) showed that the impact of $g_{s}$ on $\lambda E$ depends on the ratio between $g_{s}$ and aerodynamic conductance $\left(g_{a}\right)$ as a result of the feedback of the canopy's microclimate on $\lambda E$.

*E-mail: bjorn.dirks@altavista.com
Changes in $g_{s}$ and $\lambda E$ are reflected in the Bowen ratio $(\beta=H / \lambda E)$. Reduced $\lambda E$ as a result of changes in $\mathrm{g}_{\mathrm{s}}$ leads to higher surface temperatures. The temperature difference between the surface and air in turn determines both $\lambda \mathrm{E}$ and $\mathrm{H}$. Simulation studies have shown that $\beta$ has a pronounced effect on the development of mesoscale circulations in the atmospheric boundary layer (Segal et al. 1988, Avissar \& Pielke 1991, M ascart et al. 1991) - primarily through a differential distribution of $\mathrm{H}$ over the land surface.

$g_{s}$ is generally derived from measurements of the $\lambda \mathrm{E}$. The best established component of $\mathrm{g}_{\mathrm{s}}$ is stomatal conductance, which is affected by a number of factors: $\mathrm{CO}_{2}$ assimilation (Collatz et al. 1991), irradiance and temperature (Avissar et al. 1985, Lindroth \& Halldin 1986, Baldocchi et al. 1991), vapour pressure deficit (Price \& Black 1990, Leuning 1995, Verhoef et al. 1996), relative air humidity (Collatz et al. 1991), leaf water potential (Lynn \& Carlson 1990), גE (Mott \& Parkhurst 1991), and soil moisture. 
This paper reports on micrometeorological energy flux measurements in intensively managed peat pasture made during 2 consecutive years. Since $g_{s}$ is the most uncertain factor in the energy balance, the analysis largely focuses on $\mathrm{g}_{\mathrm{s}}$. The analysis has 2 successive objectives: firstly, it determines how $\mathrm{g}_{\mathrm{s}}$ was influenced by physical environmental variables; secondly, it demonstrates how $\mathrm{g}_{\mathrm{s}}$ determines $\lambda \mathrm{E}$ and how this interacted with the dynamics of the energy balance as a whole.

\section{MATERIALS AND METHODS}

2.1. Experimental site. $M$ easurements were made at the experimental site of the Royal Netherlands M eteorological Institute (KNMI) near Cabauw in The Netherlands $\left(51^{\circ} 58^{\prime} \mathrm{N}, 4^{\circ} 55^{\prime} \mathrm{E}\right)$. It was surrounded by pasture, orchards, minor roads and a built-up area. The soil consisted of a 0.6 to $0.8 \mathrm{~m}$ thick layer of alluvial clay on top of a massive peat layer. The land was composed of long strips alternated by waterways (every $50 \mathrm{~m}$, approximately $5 \%$ of the total surface). The vertical distance between land and waterway surface amounted to approximately $0.8 \mathrm{~m}$. The pasture predominantly consisted of Lolium perenne and was used for intensive dairy farming ( 2.5 head of cattle ha ${ }^{-1}$ ), with mixed grazing and mowing.

2.2. Flux measurements. Micrometeorological energy exchange measurements were made by the Netherlands Energy Research Foundation (ECN) by applying the aerodynamic gradient technique (Hensen et al. 1997). The measurements covered most of the periods March 1993 up to February 1994 ('1993'), and M arch 1994 up to February 1995 ('1994').

The aerodynamic gradient technique used wind speed measured at $10 \mathrm{~m}$ height. It was determined with an accuracy of $1 \%$ using a Gill propeller vane type $8002 \mathrm{dx}$, modified by KNMI. Temperature measurements were obtained at $0.6,2$ and $10 \mathrm{~m}$ height; thermocouples measured the direct differences between the successive levels. At $0 \mathrm{~m}$ height the thermocouples were measured against a $0^{\circ} \mathrm{C}$ ice bath. The thermocouples were shielded and ventilated; the accuracy of the temperature differences was approximately $0.05^{\circ} \mathrm{C}$. Air humidity followed from air temperature and wet bulb temperature; the set-up for the latter measurement was similar to that of air temperature, but the sensor was kept wet using peristaltic pumps.

Values for the following variables were clustered to $30 \mathrm{~min}$ averages: $\lambda \mathrm{E}\left(\mathrm{W} \mathrm{m}^{-2}\right)$; $\mathrm{H}\left(\mathrm{W} \mathrm{m}^{-2}\right)$; wind speed at $10 \mathrm{~m}$ height $\left(\mathrm{u}_{10}\right.$; $\left.\mathrm{m} \mathrm{s}^{-1}\right)$; air temperature at $0.6 \mathrm{~m}$ height $\left(\mathrm{T}_{\mathrm{a}} ;{ }^{\circ} \mathrm{C}\right)$; specific air humidity at $0.6 \mathrm{~m}$ height $\left(\mathrm{q} ; \mathrm{g} \mathrm{kg}^{-1}\right)$; vapour pressure deficit at $0.6 \mathrm{~m}$ height $\left(\mathrm{D}_{0.6} ; \mathrm{kPa}\right)$.

2.3. Meteorological measurements. Meteorological measurements and data processing were made by KNMI. Short-wave irradiance $(0.3$ to $3 \mu \mathrm{m})$ was measured using a Kipp CM 11 pyranometer, ventilated to prevent condensation on the dome; for diffuse irradiance the pyranometer was equipped with a shadow band. Long-wave irradiance (3 to $50 \mu \mathrm{m}$ ) was measured using a ventilated Eppley radiometer. M easurement of net radiation $(0.3$ to $50 \mu \mathrm{m})$ was made using a Funk radiometer. $\mathrm{G}$ was measured using flux plates developed by the TNO Institute of Applied Physics: 3 heat flux plates, $3 \mathrm{~m}$ apart, at 0,5 and $10 \mathrm{~cm}$ depth. Values for the following variables were clustered to 30 min averages $\left(\mathrm{W} \mathrm{m}^{-2}\right)$ : short-wave irradiance $\left(\mathrm{R}_{\mathrm{s}}\right)$, diffuse short-wave irradiance, outgoing long-wave radiation ( $\left.L_{\text {out }}\right)$, net radiation $\left(R_{n}\right)$, and $G$. The surface temperature $\left(\mathrm{T}_{s} ;{ }^{\circ} \mathrm{C}\right)$ was calculated using the StefanBoltzmann Law and $L_{\text {out }}$. A surface emissivity of 0.975 was assumed (Ripley \& Redmann 1976). The surface to air temperature difference was calculated thus: $\Delta T=$ $\mathrm{T}_{\mathrm{s}}-\mathrm{T}_{\mathrm{a}}$. Though $\Delta \mathrm{T}$ holds many uncertainties, it was assumed to be indicative of the actual surface to air temperature difference.

2.4. Analysis of measurements. Only measurements made while the wind direction was between $195^{\circ}$ and $250^{\circ}$ were analysed. In this range the fetch exclusively consisted of pasture over a distance of 1.5 to $2 \mathrm{~km}$. By restricting the analysis to measurements made during westerly winds, an implicit selection for climate type was introduced. Table 1 shows significant $(p<0.10)$ climatic differences between the $1^{\circ}$ to $360^{\circ}$ and $195^{\circ}$ to $250^{\circ}$ ranges. M ore clouds and precipitation and lower irradiance and temperature extremes indicate that we considered a climate that was slightly more maritime than the actual average. The aerodynamic technique also excluded measurements under wind-still conditions.

Table 1. Average, minimum and maximum values of environmental variables measured while the wind direction was between $1^{\circ}$ and $360^{\circ}$ and between $195^{\circ}$ and $250^{\circ}$ near Cabauw, The N etherlands, from M arch 1993 up to February 1995. All differences between the variables in the 2 ranges were significant $(p<0.10)$

\begin{tabular}{|c|c|c|c|c|c|c|}
\hline & \multicolumn{3}{|c|}{$\begin{array}{c}1^{\circ}-360^{\circ} \\
\text { Avg. Min. Max. }\end{array}$} & \multicolumn{3}{|c|}{$\begin{array}{c}195^{\circ}-250^{\circ} \\
\text { Avg. Min. Max }\end{array}$} \\
\hline Air temperature $\left({ }^{\circ} \mathrm{C}\right)$ & 9.8 & -8.2 & 32.6 & 9.9 & -6.8 & 25.7 \\
\hline Short-wave irradiance $\left(\mathrm{W} \mathrm{m}^{-2}\right)$ & 115 & - & 985 & 94 & - & 954 \\
\hline Diffuse fraction & 0.68 & - & - & 0.80 & - & - \\
\hline Air humidity $\left(\mathrm{g} \mathrm{kg}^{-1}\right)$ & 6.74 & - & - & 6.87 & - & - \\
\hline Precipitation $\left(\mathrm{mm} \mathrm{1}^{1 / 2} \mathrm{~h}^{-1}\right)$ & 0.049 & - & - & 0.058 & - & - \\
\hline
\end{tabular}


The fluxes were an average of the different states within the fetch of $1.5 \mathrm{~km}$. An increasingly delayed regrowth of grass as the season progresses results in a gradually decreasing average leaf area. Leaf area and leaf characteristics (morphology, physiological response and stomatal conductance; Davies 1988) both affect $g_{\mathrm{s}}$ (M ascart et al. 1991, Saugier \& Katerji 1991, Kelliher et al. 1995). Measurements were generally analysed at a monthly time scale. A distinction was made between daytime and nighttime measurements.

Linear regression was done by the least squares technique; non-linear regression analysis followed the iterative Marquardt-Levenberg algorithm (Fox et al. 1994).

2.5. Closure of energy balance. In the pasture's energy balance, both advection and biochemical and physical energy storage were neglected. Fig. 1 shows a close correspondence of the energy available for upward dissipation $\left(R_{\text {in }}=R_{n}-G\right)$ and actual upwardly dissipated energy $\left(R_{\text {out }}=\lambda E+H\right)$, despite the different spatial scales for the components ( $H$ and $\lambda E, 1 \mathrm{~km}^{2} ; R_{n}$ and $\mathrm{G}, 1 \mathrm{~m}^{2}$ ). No significant difference between $R_{\text {in }}$ and $R_{\text {out }}$ was observed during either year.

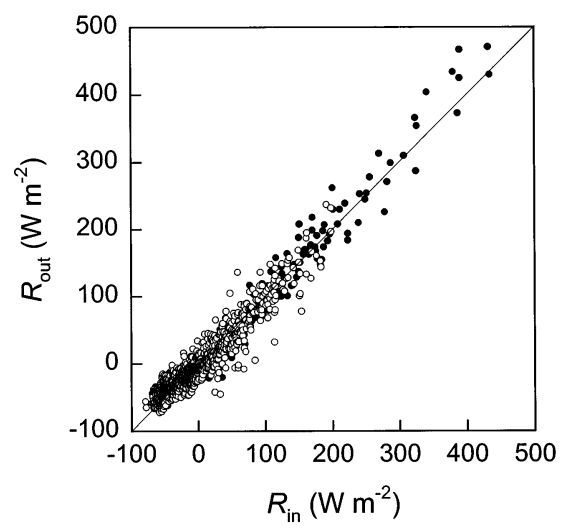

Fig. 1. Energy balance for the pasture near Cabauw, The Netherlands, in 1993 (•) and 1994 (o): comparison of available energy $\left(R_{\text {in }}=R_{n}-G\right)$ and outgoing energy $\left(R_{\text {out }}=\lambda E+H\right)$ in the wind direction $195^{\circ}-250^{\circ}$. $R_{n}$ : net radiation; $G$ : soil heat flux; $\lambda \mathrm{E}$ : latent heat flux; $\mathrm{H}$ : sensible heat flux

2.6. Latent heat flux and surface conductance. Key to the surface energy balance is the relation between $g_{s}$ and $\lambda E . g_{s}$ is the mediating (surface) factor that operates in a system of otherwise external (aerial and radiative) factors. $g_{s}$ as such cannot be measured but is derived from measurements of $\lambda \mathrm{E}$. In the analysis of the dynamics of the energy balance, 3 successive stages were distinguished: (1) the relationship between $g_{s}$ and environmental factors; (2) the relationship between $\lambda E$ and $g_{s}$; and (3) the relationship between $\beta, \lambda E$ and $g_{s}$. As for now, the first two will be considered.

Two relationships that relate the $\lambda E$ to environmental and surface factors were applied. The latent heat loss equation was used for the analysis of the dynamics of $\lambda \mathrm{E}$. The Penman-M onteith equation was used to calculate $g_{s}$ that was subsequently analysed in relation to environmental factors.

The latent heat loss equation causally relates $\lambda E$ to environmental and surface factors (M onteith \& Unsworth 1990):

$$
\lambda E=\left(0.622 \lambda \rho_{a} / p\right)(D+s \Delta T) /\left(r_{a}+r_{s}\right)
$$

where $\rho_{a}$ is the density of the dry air $\left(\mathrm{g} \mathrm{m}^{-3}\right), \mathrm{p}$ the air pressure $(\mathrm{kPa}), \mathrm{D}$ the aerial vapour pressure deficit $(\mathrm{kPa}), \Delta \mathrm{T}$ the difference between $\mathrm{T}_{\mathrm{s}}$ and $\mathrm{T}_{\mathrm{a}}\left({ }^{\circ} \mathrm{C}\right)$, s the slope of the saturation vapour pressure curve at $T_{a}$ $\left(\mathrm{kPa} \mathrm{K}^{-1}\right), \mathrm{r}_{\mathrm{a}}$ and $\mathrm{r}_{\mathrm{s}}$ the aerodynamic and surface resistances to water vapour transfer $\left(\mathrm{s} \mathrm{m}^{-1}\right)$, and $\lambda$ the latent heat of vaporisation $\left(\mathrm{J} \mathrm{g}^{-1}\right)$. Eq. (1a) was used for the analysis of the dynamics of $\lambda E$ only, because of the uncertainty in the application of $\Delta T$.

The Penman-Monteith equation is derived from Eq. (1a) and mathematically rather than causally relates $\lambda E$ to environmental and surface factors ( $M$ onteith \& Unsworth 1990):

$$
\lambda E=\left[s\left(R_{n}-G\right)+\rho_{a} c_{p} D / r_{a}\right] /\left[s+\gamma\left(r_{a}+r_{s}\right) / r_{a}\right]
$$

where $\gamma$ is the psychrometer constant $\left(\mathrm{kPa} \mathrm{K}^{-1}\right)$; and $\mathrm{c}_{\mathrm{p}}$ the specific heat of air at constant pressure $\left(\mathrm{J} \mathrm{g}^{-1} \mathrm{~K}^{-1}\right)$. Aerodynamic conductance, $\mathrm{g}_{\mathrm{a}}$, was calculated as $\left(\mathrm{u}_{0.6} / \mathrm{u}^{2}+5.31 \mathrm{u} *^{-2 / 3}\right)^{-1}$ (Thom 1972, 1975, verma et al. 1986, Monteith \& Unsworth 1990, Lhomme 1991, Saugier \& Katerji 1991), where $u_{*}$ is the friction velocity $\left(\mathrm{m} \mathrm{s}^{-1}\right) . \mathrm{u}_{0.6}$ was calculated from the logarithmic wind profile, with $u_{*}=0.141 u_{10}$, zero plane displacement $=0.05 \mathrm{~m}$, and roughness length, $\mathrm{z}_{0}=0.021$ to $0.066 \mathrm{~m}$.

Calculation of $\mathrm{g}_{\mathrm{s}}$ from Eq. (1b) involves several variables. A comparison was made between $g_{s}$ that includes all these variables and $g_{s}$ that assumes constants for several of these variables: $\mathrm{G}\left(0 \mathrm{~W} \mathrm{~m}^{-2}\right), \mathrm{p}$ $(101 \mathrm{kPa}), \gamma\left(0.066 \mathrm{kPa} \mathrm{K}^{-1}\right), \lambda\left(2477 \mathrm{~J} \mathrm{~g}^{-1}\right), \rho_{\mathrm{a}}(1246 \mathrm{~g}$ $\left.\mathrm{m}^{-3}\right)$ and $\mathrm{z}_{0}(0.03 \mathrm{~m})$. The 2 conductances did not differ significantly. Fig. 2 compares the values of total conductance to water vapour transfer, $g=\left(g_{a}+g_{s}\right) /\left(g_{a} \times\right.$ $\left.g_{s}\right)$, calculated with and without the assumption of constants. We used the $g_{s}$ calculated with the assumed constants.

2.7. Surface conductance and environment. $g_{s}$ is correlated with $\mathrm{CO}_{2}$ assimilation, but is also influenced by vapour pressure. A multiplicative relationship was used to analyse the surface conductance as a function of $R_{s}$ and surface vapour pressure deficit $\left(D_{0}\right)$. A rectangular hyperbolic relationship between $R_{s}$ and $g_{s}$ 


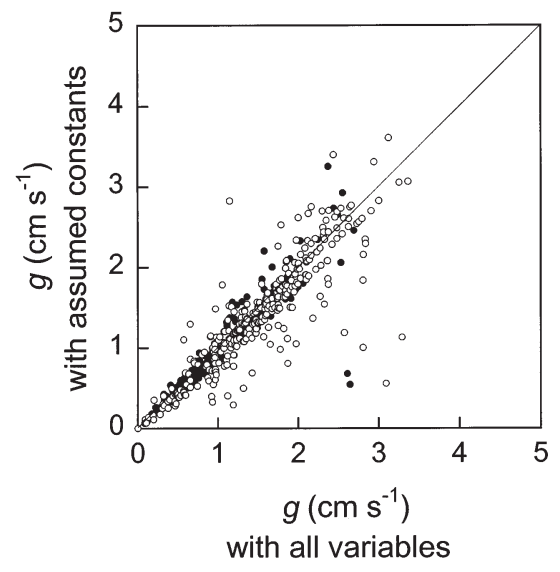

Fig. 2. Comparison of daytime conductance to water vapour transfer (g) with and without several variables assumed constant in 1993 (•) and 1994 (o)

which is characterised by $g_{s, m x}$ as the maximum surface conductance was assumed (Kelliher et al. 1995, Schulze et al. 1995).

Three different relationships between $D_{0}$ and $g_{s}$ were evaluated: (a) linear; (b) negatively exponential (J ones 1992); and (c) hyperbolic (Leuning 1995, Schulze et al. 1995):

$$
\begin{aligned}
& f\left(D_{0}\right)=1-\left(D_{0}-D_{i}\right) / d_{\text {lin }} \\
& f\left(D_{0}\right)=e^{-\left(D_{0}-D_{i}\right) / d_{\text {exp }}} \\
& f\left(D_{0}\right)=\left[1+\left(D_{0}-D_{i}\right) / d_{\text {hyp }}\right]^{-1}
\end{aligned}
$$

where $f\left(D_{0}\right)$ is the relative effect of $D_{0}$ on $g_{s}, D_{i}$ is the vapour pressure deficit inflection point with $f\left(D_{0}\right)=1$ for $D_{0}<D_{i}$, and $d_{\text {lin }}, d_{\text {exp }}$ and $d_{\text {hyp }}$ are equation-specific parameters.
Table 2. Explained variance $\left(r^{2}\right)$ and fitted parameters $(p<$ $0.10)$ for surface conductance $\left(g_{s}\right)$ as a hyperbolic function of short-wave irradiance $\left(R_{s}\right)$ and an exponential function of vapour pressure deficit $\left(D_{0}\right)$ in the wind direction range $195^{\circ}-250^{\circ} ; \lambda \mathrm{E}$ and $\lambda \mathrm{E}_{\mathrm{eq}}>0 \mathrm{~W} \mathrm{~m}^{-2} ; \Omega<0.70$. $\mathrm{D}_{0.6}$ : vapour pressure deficit at $0.6 \mathrm{~m}$ ( $p_{95}$ : 95 percentile). $g_{\mathrm{s}, \mathrm{mx}}$ : maximum surface conductance; $d_{\text {exp }}$ : parameter of exponential relationship;

\begin{tabular}{|c|c|c|c|c|c|c|c|}
\hline \multirow[b]{2}{*}{ Apr 1993} & \multirow{2}{*}{$\begin{array}{c}\begin{array}{c}\mathrm{D}_{0.6} \\
\left(\mathrm{p}_{55}\right) \\
(\mathrm{kPa})\end{array} \\
0.79\end{array}$} & \multicolumn{2}{|c|}{$\begin{array}{l}g_{s}=f\left(R_{s}\right) \\
n \quad r^{2}\end{array}$} & \multicolumn{4}{|c|}{$r^{2} \begin{array}{c}g_{s}=f\left(R_{s}, D_{0}\right) \\
g_{s, m x} d_{\text {exp }} \\
\left(\mathrm{cm} \mathrm{s}^{-1}\right)(\mathrm{kPa})\end{array}$} \\
\hline & & 47 & 0.04 & 0.56 & & 0.51 & \\
\hline J un 1993 & 1.39 & 42 & 0.04 & 0.50 & 3.0 & 0.78 & 0.21 \\
\hline & & 204 & & & 2.3 & 0.57 & \\
\hline & 0.98 & 141 & 0.4 & 52 & 2.7 & 1.11 & \\
\hline & & 58 & & & 5.1 & 0.63 & 0.24 \\
\hline & 0.8 & 94 & & & 3.4 & 0.38 & 0.34 \\
\hline & 0.63 & 39 & & 0.35 & 2.6 & & \\
\hline & 1.16 & 106 & & & 1.8 & & 0.40 \\
\hline & 0.58 & 31 & 0. & 0.77 & 6.9 & 0.46 & \\
\hline J an 1995 & 0.41 & 70 & 0.06 & 0.18 & 4.5 & & 0.27 \\
\hline
\end{tabular}
$D_{i}$ : vapour pressure deficit inflection point. $n$ : number of observations

For this analysis, situations with wet surfaces were excluded by only considering values of the $\lambda E$ and equilibrium latent heat flux $\left(\lambda \mathrm{E}_{\text {eq }}\right)>0 \mathrm{~W} \mathrm{~m}^{-2} \cdot \lambda \mathrm{E}_{\text {eq }}$ is $\lambda \mathrm{E}$ in a situation where the $g_{a}$ approaches 0 ; it equals $s \times$ $R_{n} /(s+\gamma)$ (J ones 1992). $s$ is the slope of the saturation vapour pressure curve at $\mathrm{T}_{\mathrm{a}}\left(\mathrm{kPa} \mathrm{K}^{-1}\right)$. Situations with a low degree of coupling between the atmosphere and surface (V arvis \& M CNaughton 1986) were excluded by only considering values where the decoupling coefficient $(\Omega)<0.70\left[\Omega=(\mathrm{s} / \gamma+1)\left(\mathrm{s} / \gamma+1+\mathrm{g}_{\mathrm{a}} / \mathrm{g}_{\mathrm{s}}\right)^{-1}\right]$. $\mathrm{D}_{0}$ was calculated from $D_{0.6}, g_{a}, \lambda E$ and $\lambda E_{e q}$ as described by Kelliher et al. (1993).

\section{RESULTS}
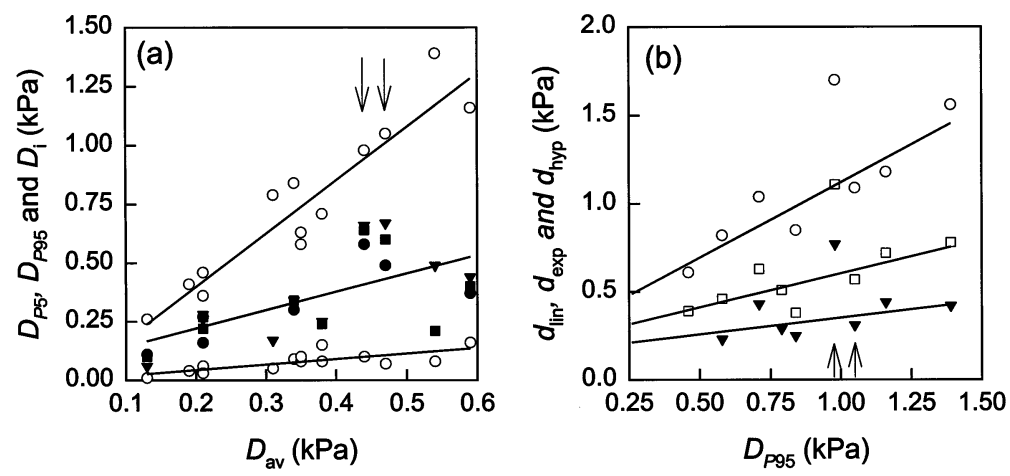

Fig. 3. (a) Monthly $p_{5}$ and $p_{95}$ ( 5 and 95 percentiles) of vapour pressure deficit ( $D ; 0)$, monthly fitted $(\bullet, \boldsymbol{\square}$ and $\boldsymbol{\nabla}$ from Eqs. $2 \mathrm{a}, 2 \mathrm{~b} \& 2 \mathrm{c}$, respectively) and regressed (--) inflection point $D_{i}$ as a function of average vapour pressure deficit $\left(D_{a v}\right)$. (b) M onthly fitted and regressed $d_{\text {lin }}(0), d_{\exp }(\square)$ and $d_{\text {hyp }}(\boldsymbol{\nabla})$ as a function of the $p_{95}$ of vapour pressure deficit $\left(D_{p 95}\right)$. Arrows: J uly and August 1993

\subsection{Surface conductance}

The fitted $g_{s, m x}$ at non-limiting irradiance and vapour pressure deficit ranged from $3-5 \mathrm{~cm} \mathrm{~s}^{-1}$ in spring and $2-3 \mathrm{~cm} \mathrm{~s}^{-1}$ in summer to $5-7 \mathrm{~cm} \mathrm{~s}^{-1}$ in autumn (Table 2 ).

$D$ was a major reducing factor of $g_{s}$ (Table 2). In increasing the explained variance, the exponential equation for the effect of $D$ was slightly more effective than the hyperbolic and linear equations. Eqs. (2b) \& (2c) altogether provided the best description for the effect of $D$ on $g_{s}$, but differences were minor.

Fig. 3a shows a positive relationship between monthly average vapour pressure deficit $\left(D_{a v}\right)$ and monthly fitted $D_{i}$ (the 
value of $D_{0}$ beyond which $g_{s}$ is progressively reduced). The range of $D$ over which $g_{s}$ was reduced $\left(D_{i}\right.$ to $\left.D_{p 95}\right)$ increased with $D_{a v}$. July and August 1993 deviated from this trend: $D_{i}$ to $D_{p 95}$ was smaller than expected.

Fig. $3 b$ shows that monthly fitted parameters $d_{\text {lin }}, d_{\text {exp }}$ and $d_{\text {hyp }}$ from Eqs. (2a), (2b) \& (2c) were positively related to $D$. In other words, the larger range of $D$ over which $g_{s}$ was reduced $\left(D_{i}\right.$ to $D_{p 95}$ ), the smaller the reduction per unit $\mathrm{D}$.

\subsection{Soil heat flux}

An upward $\mathrm{G}$ of $3 \mathrm{~W} \mathrm{~m}^{-2}$ was fitted for zero $R_{n}$ in 1993. Fig. 4 shows that the gradient of daytime $G$ against $R_{n}$ was $0.1\left(r^{2}=0.56, n=962\right)$.

\subsection{Latent heat flux}

Fig. 4 shows that the gradient of daytime $\lambda E$ against $R_{n}$ was 0.55 to $0.65\left(b_{\lambda E}\right)$ on a yearly basis. $b_{\lambda E}$ differed significantly between 1993 and 1994 ( $p<0.001)$.

In spring and summer, $b_{\lambda E}$ ranged from 0.52 to 0.70 (Table 3). The highest value of $b_{\lambda E}$ was fitted for August 1993; at this time high levels of $D$ and $g_{s}$ at moderate levels of $\Delta T$ occurred. Low values of $b_{\lambda E}$ fitted for J une 1993 and August 1994 are associated with high levels of $D$ and $\Delta T$ and low levels of $g_{s}$. The period J une to August 1993 was characterised by drought and sustained high levels of $D$, but progressively higher values
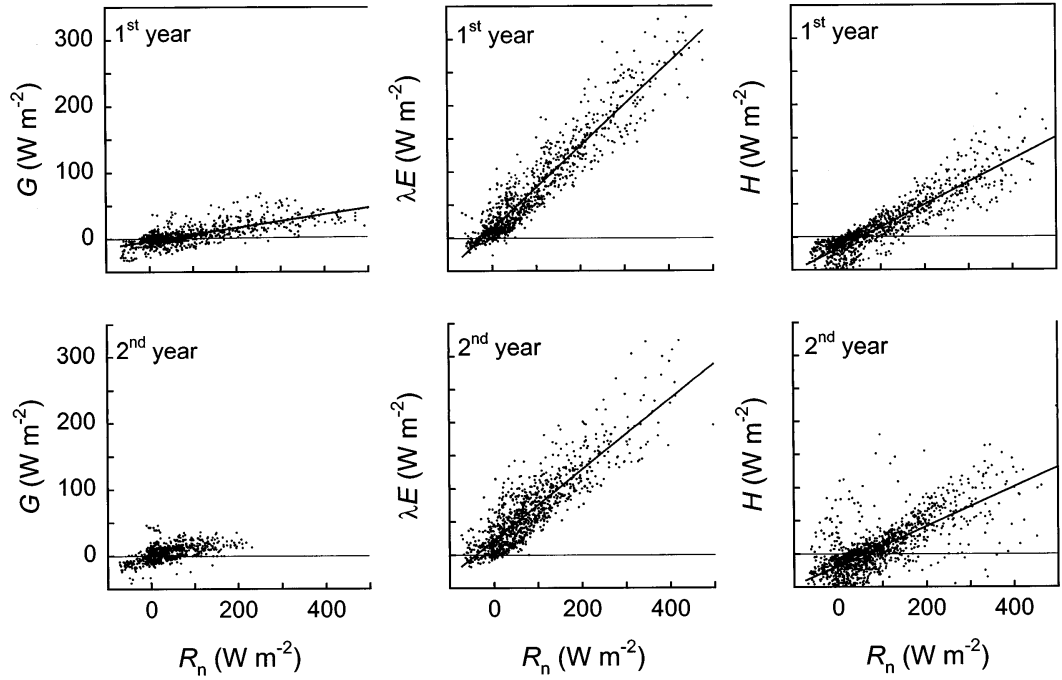

Fig. 4. Daytime soil heat flux $(G)$, latent heat flux $(\lambda E)$, and sensible heat flux $(H)$ as a function of net irradiance $\left(R_{n}\right)$ in the wind direction $195^{\circ}-250^{\circ}$ in 1993 and 1994

Table 3. Explained variance $\left(r^{2}\right)$ and regression coefficients $(p<0.10)$ for daytime latent heat flux $(\lambda E)$ and sensible heat flux $(H)$ as a linear function of the net irradiance $\left(R_{n}\right)$ in the wind direction range $195^{\circ}-250^{\circ}$. a: intercept; $b$ : slope. $R_{n}>100 \mathrm{~W} \mathrm{~m}^{-2}$. $D_{0.6}$ : vapour pressure deficit at $0.6 \mathrm{~m} ; \Delta \mathrm{T}$ : surface to air temperature difference; $g_{\mathrm{s}}$ : surface conductance; $\mathrm{n}$ : number of observations

\begin{tabular}{|c|c|c|c|c|c|c|c|c|c|c|c|c|}
\hline & \multicolumn{4}{|c|}{$p_{5}-p_{95}$} & \multirow{2}{*}{\multicolumn{4}{|c|}{$\begin{array}{c}\lambda E=f\left(R_{n}\right) \\
\left(W m^{-2}\right)\end{array}$}} & \multirow{2}{*}{\multicolumn{4}{|c|}{$\begin{array}{c}H=f\left(R_{n}\right) \\
\left(W m^{-2}\right)\end{array}$}} \\
\hline & \multirow{2}{*}{$\begin{array}{c}\mathrm{D}_{0.6} \\
(\mathrm{kPa})\end{array}$} & \multirow{2}{*}{$\begin{array}{l}\Delta \mathrm{T} \\
\left({ }^{\circ} \mathrm{C}\right)\end{array}$} & \multirow{2}{*}{$\begin{array}{c}\mathrm{g}_{\mathrm{s}} \\
\left(\mathrm{cm} \mathrm{s}^{-1}\right)\end{array}$} & \multirow[t]{2}{*}{$\mathrm{n}$} & & & & & & & & \\
\hline & & & & & $a_{\lambda E}$ & $b_{\lambda E}$ & $r^{2}$ & $\mathrm{n}$ & $a_{H}$ & $b_{H}$ & $r^{2}$ & $\mathrm{n}$ \\
\hline Apr 1993 & $0.1-0.8$ & $0.2-5.7$ & $1.3-3.8$ & 31 & 12 & 0.62 & 0.95 & 66 & -19 & 0.31 & 0.78 & 116 \\
\hline J un 1993 & $0.2-1.4$ & $0.3-6.0$ & $0.4-2.8$ & 30 & 18 & 0.55 & 0.94 & 70 & -18 & 0.36 & 0.90 & 74 \\
\hline J ul 1993 & $0.2-1.1$ & $1.1-4.9$ & $0.6-3.7$ & 146 & 12 & 0.62 & 0.87 & 283 & -12 & 0.36 & 0.84 & 292 \\
\hline Aug 1993 & $0.2-1.4$ & $0.1-5.6$ & $0.9-3.6$ & 93 & 12 & 0.70 & 0.90 & 178 & -15 & 0.27 & 0.81 & 188 \\
\hline Sep 1993 & $0.1-0.7$ & $0.6-4.1$ & $1.0-4.7$ & 45 & 14 & 0.66 & 0.87 & 69 & -19 & 0.35 & 0.86 & 74 \\
\hline Apr 1994 & $0.1-0.9$ & $0.4-5.8$ & $0.9-6.5$ & 61 & 25 & 0.52 & 0.76 & 127 & -18 & 0.31 & 0.73 & 161 \\
\hline May 1994 & $0.2-0.7$ & $0.4-3.0$ & $1.4-2.9$ & 37 & 15 & 0.63 & 0.89 & 48 & 5 & 0.23 & 0.03 & 52 \\
\hline Aug 1994 & $0.3-1.2$ & $0.7-8.5$ & $0.4-2.2$ & 74 & 16 & 0.52 & 0.83 & 138 & -19 & 0.39 & 0.90 & 144 \\
\hline Sep 1994 & $0.2-0.7$ & $0.6-2.7$ & $0.8-4.2$ & 41 & 10 & 0.68 & 0.85 & 99 & -21 & 0.32 & 0.83 & 111 \\
\hline Oct 1994 & $0.3-0.6$ & $1.0-4.6$ & $1.4-3.0$ & 16 & 22 & 0.55 & 0.78 & 87 & -21 & 0.38 & 0.86 & 91 \\
\hline Feb 1995 & $0.2-0.4$ & $0.0-1.4$ & $1.6-3.8$ & 55 & 28 & 0.53 & 0.63 & 217 & -34 & 0.37 & 0.65 & 222 \\
\hline
\end{tabular}



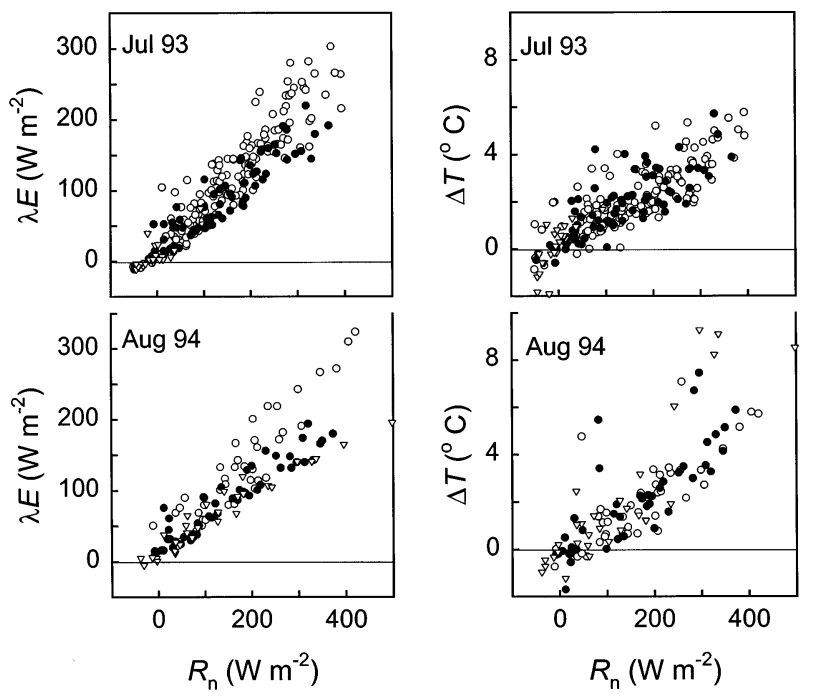

In spring and summer, $b_{H}$ ranged from 0.23 to 0.39 (Table 3). The lowest value of $b_{H}$ was fitted for August 1993 at the same time as the highest value of $b_{\lambda E} . \Delta T$ was lowest in August 1993. High values of $b_{H}$ were fitted for J une and J uly 1993 and August 1994, generally months with lower values of $b_{\lambda E}$. Levels of $\Delta T$ were relatively high in these months.

Different degrees of dissipation of daytime $\mathrm{R}_{n}$ into $\mathrm{H}$ were observed when distinguishing between different $\mathrm{g}_{\mathrm{s}}$ classes (Fig. 5). The regression coefficients in Table $4\left(a_{H}\right.$ and $\left.b_{H}\right)$ show that the dissipation of $R_{n}$ into $H$ increased with decreasing $g_{s}$ from the highest to the middle $g_{s}$ class, but remained approximately constant in the transition from the middle to the lowest $\mathrm{g}_{\mathrm{s}}$ class. Table 4 also shows that the increase in $\Delta T$ with increasing $R_{n}\left(b_{\Delta T}\right)$ generally remained constant with decreasing $g_{s}$ (Fig. 5). In August 1994, $b_{\Delta T}$ increased and $g_{a}$

Table 4. Average aerodynamic conductance $\left(g_{a}\right)$ and regression coefficients $(p<0.10)$ for daytime latent heat flux $(\lambda E)$, sensible heat flux $(H)$ and surface to air temperature difference $(\Delta T)$ as a linear function of net irradiance for different surface conductance $\left(\mathrm{g}_{\mathrm{s}}\right)$ classes in the wind direction range $195^{\circ}-250^{\circ}$ in J uly 1993 and August 1994. a: intercept; b: slope.

Superscripts indicate within-month differences $(p<0.10)$

\begin{tabular}{|lcccccc|}
\hline \multirow{2}{*}{ Parameter } & \multicolumn{5}{c|}{$\mathrm{g}_{\mathrm{s}}\left(\mathrm{cm} \mathrm{s}^{-1}\right)$} \\
& July 1993 & \multicolumn{3}{c}{ August 1994 } \\
& $>1.0$ & $0.5-1.0$ & $>1.0$ & $0.5-1.0$ & $<0.5$ \\
\hline $\mathrm{g}_{\mathrm{a}}\left(\mathrm{cm} \mathrm{s}^{-1}\right)$ & $3.6^{\mathrm{a}}$ & $3.2^{\mathrm{a}}$ & $3.0^{\mathrm{a}}$ & $3.1^{\mathrm{a}}$ & $2.2^{\mathrm{b}}$ \\
$\mathrm{a}_{\lambda \mathrm{E}}\left(\mathrm{W} \mathrm{m}^{-2}\right)$ & $16^{\mathrm{a}}$ & $14^{\mathrm{a}}$ & & $19^{\mathrm{a}}$ & $17^{\mathrm{a}}$ \\
$\mathrm{b}_{\lambda \mathrm{E}}$ & $0.66^{\mathrm{a}}$ & $0.51^{\mathrm{b}}$ & $0.68^{\mathrm{a}}$ & $0.44^{\mathrm{b}}$ & $0.39^{\mathrm{b}}$ \\
$\mathrm{a}_{\mathrm{H}}\left(\mathrm{W} \mathrm{m}^{-2}\right)$ & $-16^{\mathrm{a}}$ & $-20^{\mathrm{a}}$ & $-26^{\mathrm{a}}$ & $-25^{\mathrm{a}}$ & $-16^{\mathrm{b}}$ \\
$\mathrm{b}_{\mathrm{H}}\left({ }^{\circ} \mathrm{C}\right)$ & $0.33^{\mathrm{a}}$ & $0.49^{\mathrm{b}}$ & $0.36^{\mathrm{a}}$ & $0.47^{\mathrm{b}}$ & $0.41^{\mathrm{b}}$ \\
$\mathrm{a}_{\Delta \mathrm{T}}\left({ }^{\circ} \mathrm{C}\right)$ & $0.5^{\mathrm{a}}$ & $0.4^{\mathrm{a}}$ & & & \\
$\mathrm{b}_{\Delta \mathrm{T}}$ & $0.010^{\mathrm{a}}$ & $0.011^{\mathrm{a}}$ & $0.014^{\mathrm{a}}$ & $0.015^{\mathrm{a}}$ & $0.022^{\mathrm{b}}$ \\
$\left.{ }^{\circ} \mathrm{C}\left(\mathrm{W} \mathrm{m^{-2 }}\right)^{-1}\right]$ & & & & & \\
\hline
\end{tabular}
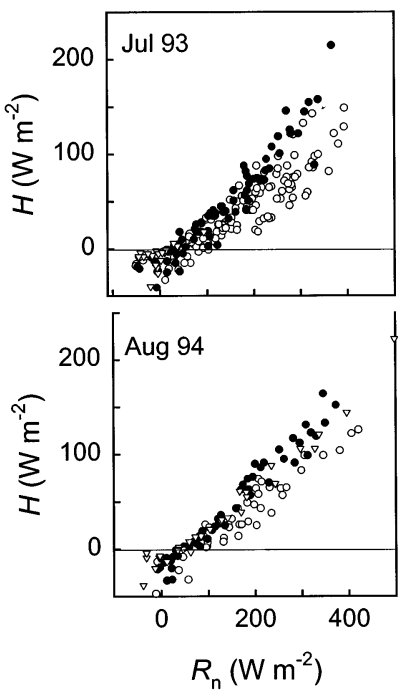

Fig. 5. Daytime latent heat flux $(\lambda E)$, sensible heat flux $(H)$, and surface to air temperature difference $(\Delta T)$ as a function of net irradiance $\left(R_{n}\right)$ in the wind direction $195^{\circ}-250^{\circ}$ in J uly 1993 and August 1994 for the following surface conductance $\left(\mathrm{g}_{\mathrm{s}}\right)$ classes: $>1.0(0), 0.5-1.0(\bullet)$, and $<0.5 \mathrm{~cm} \mathrm{~s}^{-1}(\nabla)$

decreased in the transition from the middle to the lowest $g_{\mathrm{s}}$ class.

Fig. 6 illustrates the approximately linear relationship between the independently determined $\Delta \mathrm{T}$ and $\mathrm{H}$ in 1993. The slope was $24 \mathrm{~W} \mathrm{~m}^{-2}\left({ }^{\circ} \mathrm{C}\right)^{-1}$ in $1993\left(\mathrm{r}^{2}=\right.$ $0.76, \mathrm{n}=2105)$ and $21 \mathrm{~W} \mathrm{~m}^{-2}\left({ }^{\circ} \mathrm{C}\right)^{-1}$ in $1994\left(\mathrm{r}^{2}=0.59\right.$, $\mathrm{n}=2701)$. The regression coefficients differed significantly $(p<0.001)$.

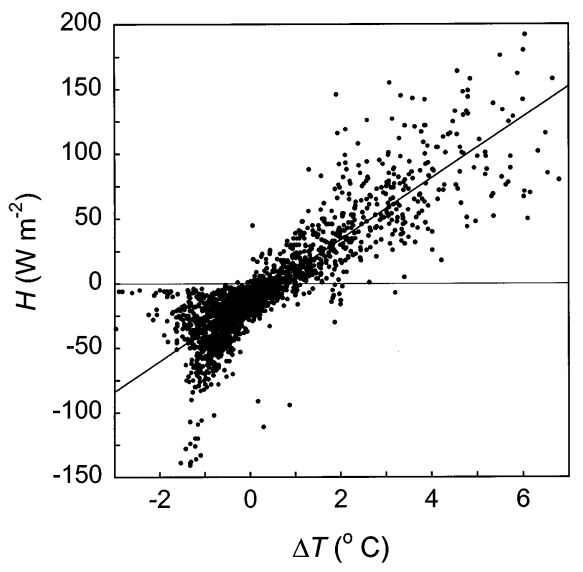

Fig. 6. Sensible heat flux $(H)$ as a function of surface to air temperature difference $(\Delta \mathrm{T})$ in the wind direction $195^{\circ}-250^{\circ}$ in 1993

\subsection{Diurnal patterns and hysteresis}

$\lambda E, H, D, \Delta T$ and $g_{s}$ were clustered to monthly average diurnal patterns. Before and after noon responses of these variables to $R_{n}$ were compared (Fig. 7).

$g_{s}$ after noon was generally lower than $g_{s}$ before noon; levels of $g_{s}$ were lower in August 1994 than in August 1993. $\lambda E$ followed the pattern of $D$, though less pronounced; the difference before and after noon was 


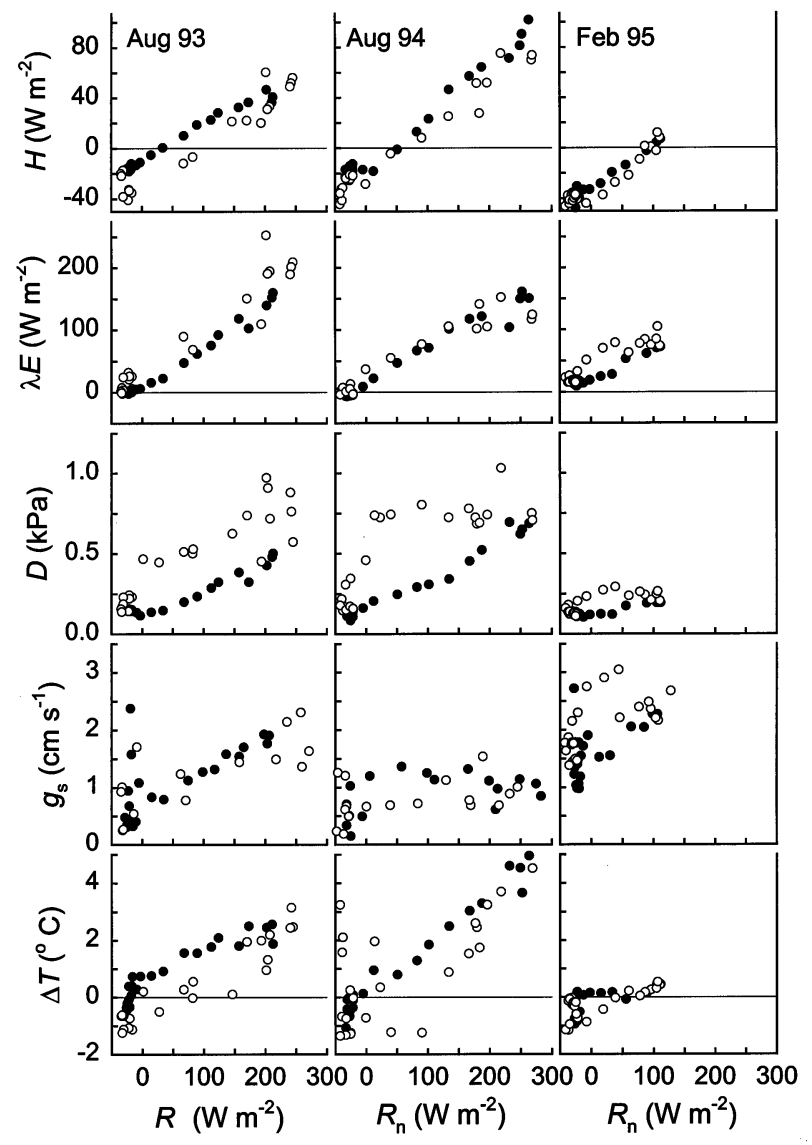

Fig. 7. Average diurnal response to net irradiance $\left(R_{n}\right)$ of the sensible heat flux $(H)$, latent heat flux $(\lambda E)$, vapour pressure deficit (D), surface conductance $\left(g_{s}\right)$ and surface to air temperature difference $(\Delta T)$ before $(\bullet)$ and after noon $(0)$ in the wind direction $195^{\circ}-250^{\circ}$ in August 1993, August 1994 and February 1995. For each $30 \mathrm{~min}$ average $n \geq 3$

lowest in August 1994. $\Delta \mathrm{T}$ after noon was lower than before noon. $\mathrm{H}$ followed the pattern of $\Delta \mathrm{T}$.

\section{DISCUSSION}

\subsection{Surface conductance}

Saugier \& Katerji (1991) and Kelliher et al. (1995) found $\mathrm{g}_{\mathrm{s}, \mathrm{mx}}$ to range from $0.9-1.7 \mathrm{~cm} \mathrm{~s}^{-1}$ in natural grassland to $3.3-5.0 \mathrm{~cm} \mathrm{~s}^{-1}$ in crops, covering the annual range found in this study. Kelliher et al. (1995) noted that fitted $\mathrm{g}_{\mathrm{s}, \mathrm{mx}}$ values tend to be approximately $25 \%$ higher than observed $g_{s, m x}$ values.

$g_{s, m x}$ as such is theoretical, since irradiance and vapour pressure deficit are positively correlated. However, the annual pattern of $g_{s, m x}$ is indicative of stable pasture characteristics. Leaf area is reflected in the long-term patterns of $g_{s, m x}$ : high after the first period of regrowth in early spring, gradually decreasing towards late autumn. This could explain most of the observed pattern of $\mathrm{g}_{\mathrm{s}, \mathrm{mx}}$.

Values of $\mathrm{g}_{\mathrm{s}, \mathrm{mx}}$ were generally speculative for autumn, since these values were never actually reached. The close relationship (Collatz et al. 1991, Leuning 1995) between $\mathrm{CO}_{2}$ assimilation and $\mathrm{g}_{\mathrm{s}}$ suggests that $\mathrm{g}_{\mathrm{s}}$ at lower irradiance may have been limited by temperature, more so in autumn than in spring or summer. This could have resulted in a reduced initial response of $g_{s}$ to irradiance and the apparently high $g_{s, m x}$.

Stomatal conductance in grass has been shown to be particularly sensitive to $D$ (Woledge et al. 1989). Fitted parameters $d_{\text {lin, }} d_{\text {exp }}$ and $d_{\text {hyp }}$ suggest effects that were stronger than found in cereals $\left(0.40 \mathrm{kPa}^{-1}\right.$; Kim et al. 1989). The exponential and hyperbolic equations for the description of the effect of $D$ on $g_{s}$ were slightly more effective than the linear equation.

The effect of $D$ on $g_{s}$ consisted of 2 components: (1) the range over which $D$ is effective $\left(D_{i}\right.$ to $\left.D_{p 95}\right)$ and (2) the reducing effect on $g_{s}$ per unit $D$ (through $d_{l i n}$, $d_{\exp }$ and $d_{\text {hyp }}$ ). Fig. 3 shows that an increasing $D$ resulted in an increase of the $D_{i}$ to $D_{p 95}$ range, despite an upward shift of $D_{i}$. An increased $D$ simultaneously resulted in a decrease in the effect on $g_{s}$ per unit $D$. This suggests that the instantaneous response of the vegetation's surface to $D$ was an adaptation to average levels of $D$. The reducing effect of $D$ on $g_{s}$ was maintained and remained distributed over most of the actual D range. Stomatal adjustment (Drake \& Salisbury 1972) traded off between $\mathrm{g}_{\mathrm{s}}$ for sustained $\mathrm{CO}_{2}$ assimilation and reduced transpiration over the full range of irradiance.

The surface response deviated from this trend in J uly and August 1993. Both the range over which $D$ affected $g_{s}$ and the effect on $g_{s}$ per unit $D$ were lower than expected. The period from J une to August 1993 was characterised by progressively lower levels of $D$. It suggests an adaptation of $\mathrm{g}_{\mathrm{s}}$ to $\mathrm{D}$ extending beyond the time frame of $1 \mathrm{mo}$.

The effects of soil moisture and $D$ on $g_{s}$ may have been confounded. However, in August 1994, a severe reduction in canopy $\mathrm{CO}_{2}$ assimilation and growth in a non-irrigated pasture on alluvial clay, $50 \mathrm{~km}$ east of the site, was largely removed by lowering D (authors' unpubl. results).

\subsection{Soil heat flux}

A $10 \%$ dissipation of $R_{n}$ into $G$ is modest. Kim \& Verma (1990) found 10 to $25 \%$ in a tallgrass prairie, where the variation was attributed to differences in surface cover and soil moisture. In temperate pastures, surface cover and soil moisture are generally high and stable relative to $R_{n}$ throughout much of the year. 


\subsection{Latent heat flux}

The effect of $D$ and $\Delta T$ on $\lambda E$ was mediated by $g_{s}$. $D$ had a direct positive effect on $\lambda E$, but beyond $D_{i}$ it simultaneously had a negative effect on $\mathrm{g}_{\mathrm{s}}$ - thus an indirect negative effect on $\lambda \mathrm{E}$. The direct and indirect effects of $D$ increasingly offset each other. J arvis (1981) found this moderation of the effect of $D$ (from $1.5 \mathrm{kPa}$ ) by $g_{s}$ in Scots pine.

The mediating effect of $g_{s}$ on the effect of $D$ was best observed in J une 1993 and August 1994 (low gs) and August 1993 (high $\mathrm{g}_{\mathrm{s}}$ ). At sustained high levels of $D, \lambda E$ increased less with $R_{n}$ at lower levels of $g_{s}$, illustrated by low $b_{\lambda E}$. Reduced $\lambda E$ co-occurred with an increased $\Delta \mathrm{T}$. August 1993 represented an 'optimum' situation $\left(b_{\lambda E} \approx 0.70\right)$.

\subsection{Sensible heat flux}

A low $g_{s}$ at high levels of $D$ reduced the $\lambda E$ and increased $\Delta T . g_{a}$ and $\Delta T$ constitute the main causal factors in $\mathrm{H}$. A reduced $\lambda \mathrm{E}$ and increased $\Delta \mathrm{T}$ in $\mathrm{J}$ une and J uly 1993 and August 1994 increased the dissipation of $R_{n}$ into sensible heat, illustrated by high $b_{H}$. August 1993 represented an 'optimum' situation $\left(b_{H} \approx 0.25\right)$.

\subsection{Bowen ratio}

At a constant $g_{s}$ J arvis (1981) found a decreasing $\beta$ when moving from a maritime to a continental climate. However, a $D$ increasing beyond $D_{i}$ decreased $g_{s}$. This progressively counteracted the increase in $\lambda \mathrm{E}$, increasing $\mathrm{H}$ through $\Delta \mathrm{T}$. In tallgrass, Kim \& Verma (1990) found $\beta$ to vary between $0.3\left(D=1.8 \mathrm{kPa}\right.$ and $\mathrm{g}_{\mathrm{s}}=$ $\left.1.3 \mathrm{~cm} \mathrm{~s}^{-1}\right)$ and $1.3\left(\mathrm{D}=4.3 \mathrm{kPa}\right.$ and $\left.\mathrm{g}_{\mathrm{s}}=0.3 \mathrm{~cm} \mathrm{~s}^{-1}\right)$. Table 4 shows that the dissipation of $R_{n}$ into $\lambda E$ and $H$ added up to increasingly lower values with decreasing $\mathrm{g}_{\mathrm{s}}$. An increased $\mathrm{G}$ may have been the result.

A simple iterative energy balance of a hypothetical leaf (J ones 1992) was calculated. It included Eq. (1a) for $\lambda E$, the standard equation for $H$ (Monteith \& Unsworth 1990) and the Stefan-Boltzmann Law for long-wave irradiance. They suggest that for 'observed' ranges of $g_{a}$ and $g_{s}, \lambda E$ is little affected by $g_{a}$. A decrease in $g_{s}$ results in a decrease in $\lambda E$ and an increase in $\Delta \mathrm{T}$ and $\mathrm{H}$; the sum of $\lambda \mathrm{E}$ and $\mathrm{H}$ is positively correlated with $g_{s}$. Low $g_{a}$ seriously reduces $\mathrm{H}$ and increases $\Delta T$, but in reality a resulting increased buoyancy may again enhance $H$.

The increase in $\lambda E$ with $R_{n}\left(b_{\lambda E}\right.$ in Table 4$)$ was tested against the steady-state theory of Eq. (1b). The increase in $\Delta T$ with $R_{n}\left(b_{\Delta T}\right.$ in Table 4$)$ was tested against the standard equation for $\mathrm{H}$ (Monteith \& Unsworth
1990). The covariance of $D$ and $R_{n}$ was $0.003 \mathrm{kPa}(\mathrm{W}$ $\left.\mathrm{m}^{-2}\right)^{-1}$, s was $0.15 \mathrm{kPa} \mathrm{K}^{-1}, \mathrm{~g}_{\mathrm{a}}$ and $\mathrm{b}_{\mathrm{H}}$ were the values in Table 4, and $\mathrm{g}_{\mathrm{s}}$ was 2.0, 0.7 and $0.4 \mathrm{~cm} \mathrm{~s}^{-1}$. For the $3 \mathrm{~g}_{\mathrm{s}}$ classes, Eq. (1b) predicts $b_{\lambda E}$ values of $0.84,0.51$ and 0.40 . The standard equation for $\mathrm{H}$ predicts $\mathrm{b}_{\Delta \mathrm{T}}$ values of $0.010,0.012$ and $0.015^{\circ} \mathrm{C}\left(\mathrm{W} \mathrm{m}^{-2}\right)^{-1}$. These predictions are lower than the observations, possibly as a result of reduced $\lambda E$ at the non-irrigated site where $\Delta T$ was determined.

\subsection{Diurnal patterns and hysteresis}

Due to hysteresis, the diurnal pattern of the energy balance gives a more accurate description of its dynamics as compared to the average parameterisation.

$D$ was the main factor in $\lambda \mathrm{E}$, since $\lambda \mathrm{E}$ was higher after than before noon, despite a lower $g_{s}$. Consequently, $\Delta \mathrm{T}$ and $\mathrm{H}$ after noon were lower than before noon, whereas a sole decrease in $g_{s}$ would have resulted in the opposite. This was observed for both a normal (1993) and a dry summer month (1994), though the dissipation of $R_{n}$ into $\lambda E$ was relatively low at drought. Baldocchi et al. (1981) observed simultaneous increases in $\mathrm{D}$ and $\lambda \mathrm{E}$ and a decrease in downward $\mathrm{CO}_{2}$ flux in soybean under conditions of heat advection; a decreased $\mathrm{g}_{\mathrm{s}}$ may have reduced $\mathrm{CO}_{2}$ assimilation but the consequence for $\lambda \mathrm{E}$ may have been compensated for by $D$.

Acknowledgements. This study was partly funded by the National Research Programme on Global Air Pollution and Climate Change (project nr. 852062). KNMI provided site facilities and processed the meteorological data. J . Goudriaan and R. Rabbinge commented on the manuscript.

\section{LITERATURE CITED}

Avissar R, Pielke RA (1991) The impact of plant stomatal control on mesoscale atmospheric circulations. Agric For Meteorol 54:353-372

Avissar R, Avissar P, Mahrer Y, Bravdo BA (1985) A model to simulate response of plant stomata to environmental conditions. Agric For M eteorol 34:21-29

Baldocchi D (1994) A comparative study of mass and energy exchange over a closed $C_{3}$ (wheat) and an open $C_{4}$ (corn) canopy: I. The partitioning of available energy into latent and sensible heat exchange. Agric For Meteorol 67: 191-220

Baldocchi DD, Verma SB, Rosenberg NJ (1981) Mass and energy exchanges of a soybean canopy under various environmental regimes. Agron J 73:706-710

Baldocchi DD, Luxmoore RJ, Hatfield J L (1991) Discerning the forest from the trees: an essay on scaling canopy stomatal conductance. Agric For M eteorol 54:197-226

Collatz GJ , Ball JT, Grivet C, Berry J A (1991) Physiological and environmental regulation of stomatal conductance, photosynthesis and transpiration: a model that includes a laminar boundary layer. Agric For M eteorol 54:107-136 
Davies A (1988) The regrowth of grass swards. In: J ones MB, Lazenby A (eds) The grass crop - the physiological basis of production. Chapman and Hall, London, p 85-127

Drake BG, Salisbury FB (1972) After effects of low and high temperature pretreatments on leaf resistance, transpiration and leaf temperature in Xanthium. Plant Physiol 50: 572-575

Fox E, Kuo J , Tilling L, Ulrich C (1994) SigmaStat user's manual. J andel Scientific, Erkrath

Hensen A, Van den Bulk WCM, Vermeulen AT, Wyers GP (1997) $\mathrm{CO}_{2}$ exchange between grassland and the atmosphere- results over a four year period of $\mathrm{CO}_{2}$ measurements at Cabauw, the Netherlands. Report ECN-C--97032. Netherlands Energy Research Foundation, Petten

Hiyama T, Sugita M, Kayane I (1995) Variability of surface fluxes within a complex area observed during TABLE 92. Agric For Meteorol 73:189-207

Jarvis PG (1981) Stomatal conductance, gaseous exchange and transpiration. In: Grace J, Ford ED, J arvis PG (eds) Plants and their atmospheric environment - the 21st Symposium of The British Ecological Society, Edinburgh 1979. Blackwell, Oxford, p 175-204

J arvis PG, M cNaughton KG (1986) Stomatal control of transpiration: scaling up from leaf to region. Adv Ecol Res 15: 1-49

J ones HG (1992) Plants and microclimate, 2nd edn. Cambridge University Press, Cambridge

Kelliher FM, Leuning R, Schulze ED (1993) Evaporation and canopy characteristics of coniferous forests and grasslands. Oecologia 95:153-163

Kelliher FM, Leuning R, Raupach MR, Schulze ED (1995) Maximum conductances for evaporation from global vegetation types. Agric For M eteorol 73:1-16

Kim J , Verma SB (1990) Components of surface energy balance in a temperate grassland ecosystem. Boundary Layer Meteorol 51:401-417

Kim J, Verma SB, Rosenberg NJ (1989) Energy balance and water use of cereal crops. Agric For M eteorol 48:135-147

Leuning R (1995) A critical appraisal of a combined stomatalphotosynthesis model for $\mathrm{C}_{3}$ plants. Plant Cell Environ 18: 339-355

Lhomme J P (1991) The concept of canopy resistance: historical survey and comparison of different approaches. Agric For M eteorol 54:227-240

Editorial responsibility: Gerd Esser, Gießen, Germany
Lindroth A, Halldin S (1986) Numerical analysis of pine forest evaporation and surface resistance. Agric For M eteorol 38: 59-79

Lynn BH, Carlson TN (1990) A stomatal resistance model illustrating plant vs. external control of transpiration. Agric For M eteorol 52:5-43

M ascart P, Taconet O, Pinty J P, Ben M ehrez M (1991) Canopy resistance formulation and its effect in mesoscale models: a HAPEX perspective. Agric For M eteorol 54:319-351

Monteith J L, Unsworth M H (1990) Principles of environmental physics, 2nd edn. Arnold, London

M ott KA, Parkhurst DF (1991) Stomatal responses to humidity in air and helox. Plant Cell and Environ 14:509-515

Price DT, Black TA (1990) Effects of short-term variation in weather on diurnal canopy $\mathrm{CO}_{2}$ flux and evapotranspiration of a juvenile douglas-fir stand. Agric For M eteorol 50: 139-158

Ripley EA, Redmann RE (1976) Grassland. In: Monteith J L (ed) Vegetation and the atmosphere, Vol 2. Academic Press, London, p 349-398

Saugier B, Katerji N (1991) Some plant factors controlling evapotranspiration. Agric For M eteorol 54:263-277

Schulze ED, Leuning R, Kelliher FM (1995) Environmental regulation of surface conductance for evaporation from vegetation. Vegetatio 121:79-87

Segal M, Avissar R, M cCumber M, Pielke RA (1988) Evaluation of vegetation effects on the generation and modification of mesoscale circulations. J Atmos Sci 45:2268-2292

Thom AS (1972) M omentum, mass and heat exchange of vegetation. Q J R M eteorol Soc 98:124-134

Thom AS (1975) Momentum, mass and heat exchange of plant communities. In: Monteith J L (ed) Vegetation and the atmosphere, Vol 1. Academic Press, London, p 57-109

Verhoef A, Allen SJ, De Bruin HAR, Jacobs CMJ, Heusinkveld BG (1996) Fluxes of carbon dioxide and water vapour from a Sahelian savanna. Agric For Meteorol 80: 231-248

Verma SB, Baldocchi DD, Anderson DE, M att DR, Clement RJ (1986) Eddy fluxes of $\mathrm{CO}_{2}$, water vapor, and sensible heat over a deciduous forest. Boundary Layer Meteorol 36: 71-91

Woledge J, Bunce JA, Tewson V (1989) The effect of air humidity on photosynthesis of ryegrass and white clover at three temperatures. Ann Bot 63:271-279

Submitted: December 5, 1997; Accepted: March 3, 1999 Proofs received from author(s): May 7, 1999 